\title{
My Sixty Years Spent with Professor Hatsujiro Hashimoto
}

\author{
Makoto Shiojiri
}

Kyoto Institute of Technology, Kyoto 606-8585, Japan.

Professor Hatsujiro Hashimoto passed away on 15 April 2017, at the time of falling cherry petals around Lake Biwa, the largest lake in Japan, where spring that year had come late. Prof. A. Howie, his long-time friend and colleague, composed a 'haiku' which is a Japanese poem consisting of seventeen $(5,7,5)$ syllables: Soft at Lake Biwa / Cherry petal fall came late / Hashi's eyelids closed, remembering Hashi, his dead respected friend，(亡き畏友 Hshi を偲びつつ，友逝きて/湖面静かに/遅桜 ). Prof. Hashimoto was born on 26 December 1921. He entered the Hiroshima University of Arts and Science (in the old education system (OES) before 1948), where in 1944 he began studies using electron diffraction methods. Almost all laboratories in the university were destroyed by the atomic bomb on 6 August 1945 and he suffered injuries from the bombing. Experimental devices and data in his room were, however, secured from the fire by an original water pool he designed, which had been built along the window. He graduated from Hiroshima in Sept. 1945. In 1947, he got a professorship at Kyoto College of Technology (OES) and started afresh to engage in academic research under Prof. Kenzo Tanaka in the Department of Physics at Kyoto University (KU). The Doctor of Science degree was conferred on Hashimoto by KU in 1953 for his 'Study of thin crystalline films by universal electron diffraction microscope'. Using this microscope (Fig. 1), he observed a variety of patterns in a $\mathrm{MoO}_{3}$, which might be one of the first observations of dislocations by diffraction contrast if he had noticed it (1954). In 1957, he succeeded in visualizing dislocations in a moiré image, confirmed by means of a different method. In 1958 when I was an undergraduate at KU, I first met Hashimoto at Tanaka's laboratory (Fig. 2), where he was engaged in his famous observation of whisker growth in a gas reaction chamber and in the calculation of electron microscopy images by the electron diffraction dynamical theory. I watched these experiments with great interest. Since then, I have always regarded Hashimoto with respect as a man of experience in my life. Hashimoto was promoted to a full professor of Kyoto Institute of Technology (KIT) in 1962. I spent a long time with him as an associate professor in KIT in 1966-1975. During these years I saw many experiments performed by Hashimoto and his collaborators. These were investigations with a gas reaction specimen chamber for electron microscopy, the nucleation of dendritic tungsten oxide crystals, and the visualization of single atoms by dark field electron microscopy, and more. Hashimoto was appointed to a professorship at Osaka University (OU) in 1972, and when he moved from KIT to OU I took over his position in 1975. At OU, he made direct observations of the movement of atoms around lattice imperfections in gold crystals using TV systems and constructed a $400 \mathrm{kV}$ analytical atom resolution electron microscope in 1985 for further work. He retired from OU in 1985. He continued as a professor at Okayama University of Science from 1985 until 2003. I would like to quote the preface in a festschrift (published in Ultramicroscopy [1]) written by Prof. M. J. Whelan who was also his long-time friend and colleague, as I share the same feelings: 'I need hardly dwell on Hashi's scientific achievements -- they are well known to all of us. He has been a major influence in the development and application of electron microscopy in Japan. From the study of crystal growth in situ, through dynamical diffraction theory of image contrast, high voltage electron microscopy, moiré fringe studies, high resolution and atom imaging techniques etc., etc. -- his contributions have simply been outstanding on the world scene. We are all indebted to him for the light he has shed on the numerous fields of application in which he has worked'. Prof. A. Howie surveyed Hashimoto's research achievements in his obituary on Hashimoto [2]. 
Prof. Hashimoto was elected as the President of Japanese Society of Electron Microscopy (JSM) in 1978. He was an Honorary Member or Fellow of many microscopy societies, including the JSM, the Chinese Society of Microscopy, the Spanish Society of Microscopy, and the Royal Microscopical Society in London. He received many awards: the Seto-Prizes in 1960 and 1972 from JSM and the Distinguished Scientist Award in 1988 from the Microscopy Society of America, and more. Further, Hashimoto was awarded the 'Medal with Purple Ribbon' in 1984 and the 'Second Class Order of the Sacred Treasure' in 1992, both from the Emperor of Japan (Fig. 3). He was elected as the President of the International Federation of Societies of Electron Microscopy in 1982, and held this office until 1986. There, he helped electron microscopists in various countries and communities, to establish their electron microscopy societies, in collaboration with Prof. G. Thomas. In 1984, thanks in large part to his efforts, the third Asia-Pacific Conference on Electron Microscopy (APCEM) was reinstated with establishment of the Committee of Asia-Pacific Societies of Electron Microscopy which elected him as the first President. We held a symposium in Professor Hashimoto's honor at the 8th APCEM in Kanazawa, Japan in 2004, expressing our great gratitude to him. He was really a man of many talents, not only in electron microscopy but also in fine arts. He was a good singer of "Utai" songs in the Japanese classical Noh play tradition and old Chinese poems, and also an excellent calligrapher of Chinese hànzì. He always carried a sketch book in his bag during travel. A book, "Scenery in the World Seen by a Microscopist -- journey through sketch for 23 years -- " was published in 1999 (ISBN4-9980747-1-7 C0071). Every New Year, we anticipated receiving his greetings card with one of his paintings and a poem. We can no longer expect a greetings card from him, and I feel very sad about this. When he stayed at Cambridge (1959-60), a colleague made a bet as to which might happen earlier: whether mankind might arrive on the moon, or his wife might walk in front of him. His wife, Mrs. Haruko Hashimoto, was a typical classic Japanese lady, modest with gentle manners. No, she never walked in front of him. Mrs. Hashimoto passed away on May 3 just two weeks after her husband. Professor and Mrs. Hashimoto were devout Buddhists in Jodo Shinsyu (The True Essence of Pure Land Teaching). In my lecture, I will review our works inspired by Prof. Hashimoto: HAADFSTEM and GaN-based LED [3,4], and an observation of live nature by new environmental SEM [5].

References:

[1] M. Whelan, Ultramicros. 54, Nos. 2-4 (1994).

[2] A. Howie, Ultramicros. 182, (2017) a1-a4.

[3] M. Shiojiri and H. Saijo, J. Micros.223, (2006) 102.

[4] H.-Y. Shih et al. Sci. Rep. 5, (2015) 13671.

[5] E. Tihlaříková et al. Micros. Microanal.19, (2013) 914.
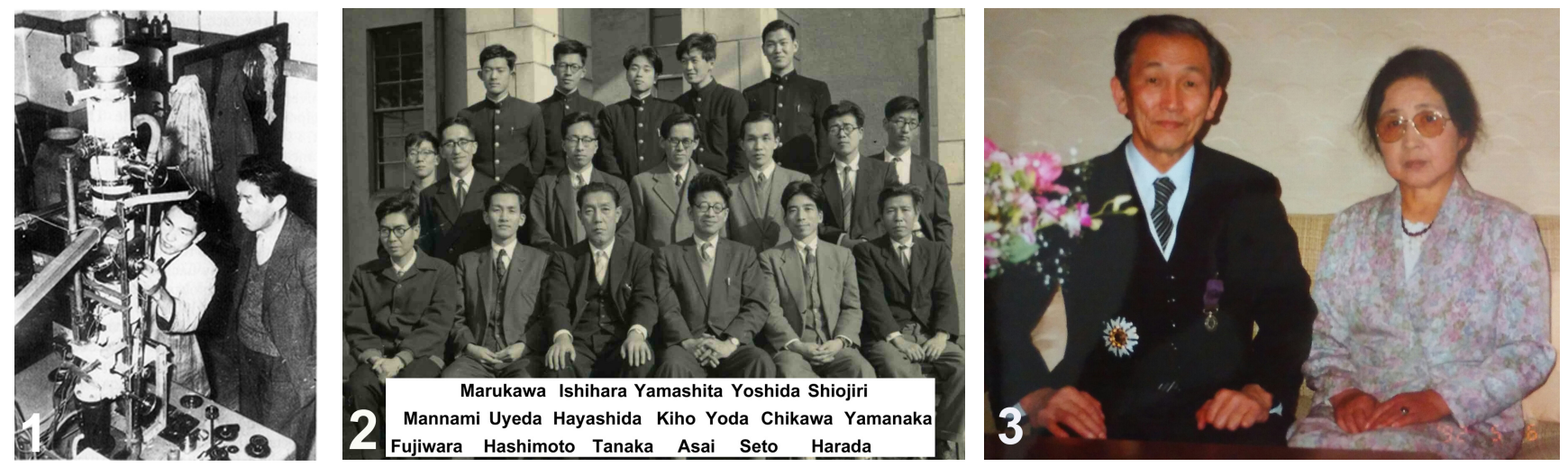

Figure 1. His universal electron diffraction microscope with Prof. Tanaka, (1953). Figure 2. Tanaka laboratory at Dept. of Physics, Kyoto University, (1958). Figure 3. Prof. and Mrs. Hashimoto, (1992). 